\title{
INDEX TO VOLUME 106
}

Bax, Beth, see Schiff, Kenneth

Beaman, Kent R., see Lovich, Jeffrey E.

Bearzi, M., see Navarro, M. O.

Cartamil, Daniel P., see Lowe, Christopher G.

Drayton, Paul K., see Parnell, P. Ed.

Fleming, Terry, see Schiff, Kenneth

Hoisington IV, Greg, see Lowe, Christopher G.

Huddleston, Richard W. and Gary T. Takeuchi. First Fossil Record of Totoaba Villamar 1980 (Teleostei: Sciaenidae) Based upon Early Miocene Otoliths from California with Comments on the Ontogeny of the Saccular Otolith. . . . . . . . . . 1

Lovich, Jeffrey E. and Kent R.Beaman. A History of Gila Monster (Heloderma suspectum cinctum) Records from California with Comments on Factors Affecting

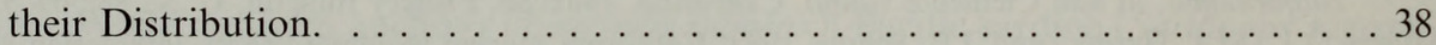

Lowe, Christopher G., Greg J. Moss, Greg Hoisington, IV, Jeremy J. Vaudo, Daniel P. Cartamil, Megan M. Marcotte, and Yannis P.Papastamatiou Caudal Spine Shedding Periodicity and Site Fidelity of Round Stingrays, Urobatis halleri (Cooper), at Seal Beach, California: Implications for Stingray-related Injury

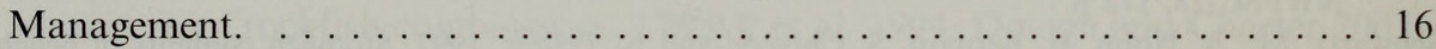

Marcotte, Megan M., see Lowe, Christopher G.

Margiotta, Francesca, see Parnell, P. Ed.

Markle, Phil, see Schiff, Kenneth

Matson, John O., see Poffenroth, Mary

Miller, Eric F. Post-Impingement Survival and Inferred Maximum Thermal Tolerances for Common Nearshore Marine Fish Species of Southern California. . . . . . 193

Moss, Greg J., see Lowe, Christopher G.

Navarro, M. O. and M. Bearzi. Affects of Marine Mammals on the Sport Fishery in

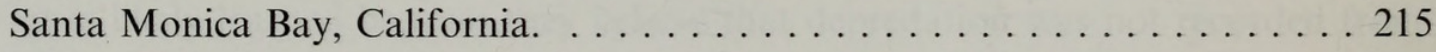

Newman, Jennifer see Schiff, Kenneth

Papastamatiou, Yannis P., see Lowe, Christopher G.

Parnell, P. Ed., Paul K. Drayton, and Francesca Margiotta. Spatial and Temporal Patterns of Lobster Trap Fishing: A Survey of Fishing Effort and Habitat Structure

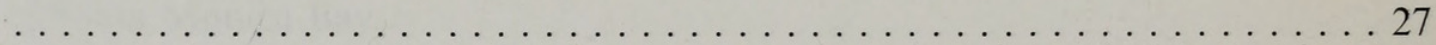

Phillips, Charles, R. Sediment Contaminant Patterns Within Coastal Areas of the Southern California Bight: Multivariate Analyses of Bight'98 Regional Monitoring

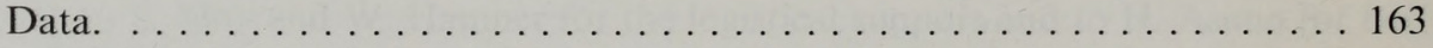

Poffenroth, Mary and John O. Matson. Habitat Partitioning by Two Sympatric species of Chipmunk (Genus Neotamias) in the Warner Mountains of California. . . 208 
Schiff, Kenneth, Beth Bax, Phil Markle, Terry Fleming, and Jennifer Newman. Wet and Dry Weather Toxicity in the San Gabriel River. . . . . . . . . . . . . . . . 179

Supplement Annual Meeting of Southern California Academy of Sciences. . . . . . . 58

Takeuchi, Gary T., see Huddleston, Richard W.

Vaudo, Jeremy J., see Lowe, Christopher G. 


\section{$2 \mathrm{BHL}$ Biodiversity Heritage Library}

2007. "Index To Volume 106." Bulletin 106(3), 218-219.

https://doi.org/10.3160/0038-3872(2007)106[218:itv]2.0.co;2.

View This Item Online: https://www.biodiversitylibrary.org/item/123214

DOI: https://doi.org/10.3160/0038-3872(2007)106[218:itv]2.0.co;2

Permalink: https://www.biodiversitylibrary.org/partpdf/292028

\section{Holding Institution}

California Academy of Sciences

\section{Sponsored by}

California Academy of Sciences Library

\section{Copyright \& Reuse}

Copyright Status: In copyright. Digitized with the permission of the rights holder.

This document was created from content at the Biodiversity Heritage Library, the world's largest open access digital library for biodiversity literature and archives. Visit BHL at https://www.biodiversitylibrary.org. 